\title{
Edification from the Andorran Model: A Brief Exploration into the Condominium Solution on the International Stage and Its Potential Application to Current Land Disputes
}

Taylor Calvin Perkins

Indiana University Maurer School of Law, taylorperkins1@gmail.com

Follow this and additional works at: https://www.repository.law.indiana.edu/ijgls

Part of the International Law Commons

\section{Recommended Citation}

Perkins, Taylor Calvin (2014) "Edification from the Andorran Model: A Brief Exploration into the Condominium Solution on the International Stage and Its Potential Application to Current Land Disputes," Indiana Journal of Global Legal Studies: Vol. 21 : Iss. 2 , Article 10.

Available at: https://www.repository.law.indiana.edu/ijgls/vol21/iss2/10

This Note is brought to you for free and open access by the Law School Journals at Digital Repository @ Maurer Law. It has been accepted for inclusion in Indiana Journal of Global Legal Studies by an authorized editor of Digital Repository @ Maurer Law. For more information, please contactrvaughan@indiana.edu.

\section{$\Psi$}

JEROME HALL LAW LIBRARY

INDIANA UNIVERSITY

Maurer School of Law
Blooming ton 


\title{
Edification from the Andorran Model: A Brief Exploration into the Condominium Solution on the International Stage and Its Potential Application to Current Land Disputes
}

\author{
TAYLOR CALVIN PERKINS*
}

\begin{abstract}
This note explores the international legal concept of the condominium solution and its current manifestation under the Andorran political system. It endeavors to come to a working definition of condominium, before embarking on a survey of condominiums throughout history. The note then chronicles the history of Andorra and the genesis of the Andorran condominium, and then analyzes the current Andorran constitution and the influence of the condominium within the document. Lastly, the paper explores why Andorra has been able to remain a condominium for over eight centuries, before finally ruminating on the optimistic future of condominium solutions in international law.
\end{abstract}

\section{INTRODUCTION}

In the insatiable rush for land and resources in the European colonial expansion of the nineteenth and early twentieth century, an ancient international legal concept was revived as a means of dealing with disputed territories between two sovereign nations. ${ }^{1}$ Known as the condominium solution, it was a territorial modus vivendi, allowing for two sovereign states to equally govern a disputed territory. However, this model would fall into disfavor by legal and political theorists in the twentieth century, as the Westphalian conception of a territory being absolutely sovereign became heralded as the paramount characteristic

* Notes Editor, Indiana Journal of Global Legal Studies; J.D., 2014, Indiana University Maurer School of Law.

1. See D. P. O'Connell, The Condominium of the New Hebrides, 43 BRIT. Y.B. INT'L L. 71,77 (1968).

Indiana Journal of Global Legal Studies Vol. 21 \#2 (Summer 2014)

(C) Indiana University Maurer School of Law 
of the nation-state. ${ }^{2}$ Consequently, despite the vast array of seemingly perennial conflicts between two states over disputed territories in the world today, ${ }^{3}$ the condominium solution is continually overlooked or dismissed by political scholars as a viable solution to these issues. ${ }^{4}$ The condominium solution remains an endangered concept in the political realm, almost entirely absent on the world stage today, save for the postage-stamp sized western European nation of Andorra. ${ }^{5}$ Perched atop the Pyrenees Mountains, this spit of territory has intriguingly endured for eight centuries as a successful political condominium. This note attempts to explore this anomalous condominium as a permanent political resolution to disputed territories in order to better understand its governmental structure and to perhaps provide suggestion as to how that structure may be employed in other disputed regions. Part I will endeavor to create a working definition of condominium, with Part II examining the two types of condominiums. Part III will then delve into the history of condominium and its development in international law. Part IV will examine the history of Andorra and the impetus for the condominium solution in the territory, with Part $\mathrm{V}$ examining the codification of the condominium solution in the modern Andorran Constitution. Finally, part VI will examine why the Andorran condominium has continued to last, with Part VII exploring the future of the condominium solution on the global stage.

\section{DEFINING Condominium}

As each regime of joint supremacy in a condominium is sui generis, legal scholars have struggled for decades to come up with an adequate definition of condominium. ${ }^{6}$ Accordingly, legal scholars have promulgated a myriad of definitions in an attempt to directly define this elusive concept. ${ }^{7}$ According to Hersch Lauterpaht, a condominium is a

2. See Joel H. Samuels, Condominium Arrangements in International Practice: Reviving an Abandoned Concept of Boundary Dispute Resolution, 29 MICH. J. INT'L L. 727, 734 (2008).

3. Id. at 729 (noting several disputed territories around the world that could potentially benefit from the Andorran model, including Gibraltar, Brcko in the former Yugoslavia, the West Bank and Gaza, the Caspian Sea, the Barents Sea, the Orange River, Jerusalem and Kashmir).

4. Id. at 730 .

5. Andorra has an area of 175 square miles. Jacob Dolinger, Application, Proof, and Interpretation of Foreign Law: a Comparative Study in Private International Law, 12 ARIz. J. INT'L \& COMP. L. 225, 239 (1995).

6. See O'Connell, supra note 1 , at 81 .

7. Vincent P. Bantz, The International Legal Status Of Condominia, 12 FLA. J. INT'L L. 77,89 (1998). 
territory "clearly under a division of sovereignty, or joint sovereignty, or both." 8 Arrigo Cavagleir held that a condominium arises when demarcating a border would be too problematic; instead, the territory is placed "pro invidiso under the contesting powers joint authority." Lassa Oppenheim described a condominium as "a piece of territory consisting of land or water ... under the joint tenancy of two or more States, [with] these several states exercising sovereignty conjointly over it, and over the individuals thereon." 10 Max Sorensen opined that a condominium existed when a territory had division of authority between two or more states. ${ }^{11}$ Lastly, Marcel Sibert argued that a condominium exists when "two or more states together exercise joint sovereignty on the same territory, and such sovereignties mutually limit their activities, at least in principle, on the grounds of legal equality."12

Other political writers have held that the idea of "joint sovereignty" is a contradiction in terms because sovereignty is inherently autonomous, thereby foreclosing the ability to hold sovereignty collectively. ${ }^{13}$ To circumvent this conundrum, these writers instead propose that a condominium is "one sovereignty whose attributes are partitioned, or exercised by two Powers at different times and in respect of different subjects and different subject matters." 14 However, this definition too has been criticized for being too tautological; indeed, critics have noted that its proponents have simply supplanted "sovereignty" with "jurisdiction," mistaking separate jurisdiction with joint jurisdiction. ${ }^{15}$

The scholar Alfred Verdross may have come up with the most productive definition of a condominium: "a condominium is a territory placed under the joint authority of two or more states [condomini] and thus subject to the different states rules, which have been issued by a joint organ."16 Under Verdross's explanation, a condominium territory does not belong to each of the two states individually, but is "under the joint jurisdiction of an international partial community."17 Moreover, states that are part of a condominium agreement are members of an organization that was created by international agreement. ${ }^{18}$ Member

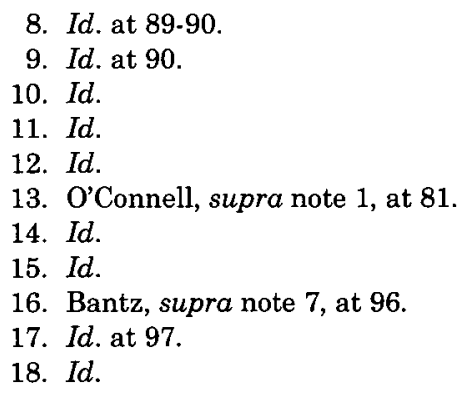


States are legally equal, endowed with the equivalent rights and duties as the other party states. ${ }^{19}$ Verdross argues that that this international community of the condominium cannot be considered as joint territory; indeed, if it were true joint authority then each Member State of the condominium would deem the condominium territory to be its own. ${ }^{20}$ Therefore, Verdross contends that it is inherent in the condominium that no state can individually claim for itself enjoyment over the whole condominium; instead, the organs of condominium government are quintessentially international. ${ }^{21}$

Building on Verdross' characterization of a condominium, Alain Coret promulgated a definition that has best captured the amorphous nature of the condominium: "the status of a territory where the enjoyment and exercise of the competences . . . belong to a partial international community characterized by juridical and functional equality of the member states; this community exercises its competences with the help of particular international organs, immediate or mediate." 22

It is this lack of international competence that remains a defining characteristic of condominiums, with a complete lack of autonomy on the international stage.23 Characterized as an absence of an "international personality," (defined as a state having purpose, autonomous will, responsibility powers, an organization, and the capacity to contribute to international law), condominiums have no treaty-making power and cannot contribute in international norm creation. ${ }^{24}$ Therefore, inherent in condominiums is an absence of an international personality that is independent of the condominium states, as only the condominium members, and not the territory, have access to the international order. ${ }^{25}$ Indeed, international treaties and negotiations are undertaken by the condomini as co-ruling states and not as organs of the condominium community. ${ }^{26}$ These condomini always make joint decisions when it comes to international negotiations, concluding the agreements in their own names, as the condominium territory lacks either treaty-making capacity or power. ${ }^{27}$

\footnotetext{
19. Id.

20. Id. at $97-98$.

21. Id. at 98 .

22. $I d$. at 99 .

23. Id. at 147 .

24. Id. at 100-01.

25. Id.

26. Id. at 147.

27. Id.
} 


\section{The Two Types of Condominium Solutions}

Condominiums have historically fallen into two subgroups depending on the condominium's proximity to the condomini: frontier or colonial. The frontier condominium occurs when the disputed territory borders the condominium Member States. ${ }^{28}$ Usually devised to resolve border disputes between neighboring states, frontier condominiums can be difficult to manage due to problems of currency crossings and boundary flow. ${ }^{29}$ Moreover, problems with citizenship, nationality, and voter participation occur more often in frontier condominiums due to minimal ethnic differences between the native condominium population and the population of the two condomini. ${ }^{30}$ Because of a state's contiguous frontier with the disputed territory, frontier condominiums usually end with one of the condomini eventually incorporating the disputed territory into its own borders. ${ }^{31}$ Due to this host of issues, a frontier condominium generally fails to last as long as a colonial condominium..$^{32}$

The classic example of the frontier condominium was found in a small swath of territory known as Moresnet. Bordering Germany, Belgium, and the Netherlands, this area was held in condominium from 1816 until 1919 by Prussia and the Netherlands. ${ }^{33}$ Arising from a disputed 1815 border treaty between the Netherlands and Prussia that had failed to expressly articulate who held the district of Moresnet, ${ }^{34}$ both the Netherlands and Prussia held competing interpretations of the treaty favoring their own claim to the land. ${ }^{35}$ In 1816 the dispute was resolved in the Treaty of Aix-la-Chappelle, an accord that established the framework of condominium rule over the disputed territory. ${ }^{36}$ The treaty created a governmental structure where legislative and executive decisions would be administered collectively by both the Prussian and Dutch states. ${ }^{37}$ However, although both the Prussian and Dutch States held the executive and legislative branches collectively, the French Code of the First Empire remained in force and could not be amended without

\footnotetext{
28. Samuels, supra note 2, at 734 .

29. Id. at 735 .

30. Id.

31. Jordie Saperia, Jerusalem: Legal Status, Condominium, and the Middle East Peace, 3 JEAIL 175, 185 (2010).

32. Samuels, supra note 2 , at 735 .

33. Id. at 740 .

34. Id.

35. Id at 741 .

36. Id.

37. Id.
} 
the consent of both France and the Netherlands. 38 Although two commissioners who represented Prussia and the Netherlands initially ruled the territory of Moresnet, the commissioners gradually granted Moresnet a greater autonomy by appointing a mayor and allowing a council to govern the district. ${ }^{39}$ The indigenous population of Moresnet was made up of citizens of both the sovereign countries. ${ }^{40}$ As citizens of both France and the Netherlands, the natives of Moresnet were given the ability to choose their country of allegiance for determining which laws would apply to them.41 Accordingly, residents of Moresnet who were subject to civil litigation could choose to have the venue be held in either the Belgian Tribunal of Verivener or the Prussian Tribunal at Aix-la-Chappelle. ${ }^{42}$ Although lasting for close to a century, the condominium ceased to exist at the close of World War I, when the Treaty of Versailles officially awarded the territory to Belgium in 1919.43

The second type of condominium is the colonial condominium; this condominium shares no borders with the Member State. The colonial condominium entered the political lexicon relatively recently, born in the nineteenth century as a means for colonial powers to co-govern a territory that both held claims to. ${ }^{44}$ Because the co-sovereign does not share natural borders with a colonial condominium, it becomes much more difficult and more expensive to maintain colonial condominiums than frontier condominiums. Consequently, colonial condominiums also more often result in the indigenous population achieving self-rule. ${ }^{45}$

The paradigmatic example of a colonial condominium was found in the West Pacific island chain of New Hebrides. ${ }^{46}$ With the discovery of sandalwood on the islands in $1825,{ }^{47}$ both Australian (and, by extension, British) and French settlers flocked to the island chain. ${ }^{48}$ After decades of escalating tensions between the two nations, France and Great Britain signed an accord in 1906 establishing a condominium over the

38. $I d$.

39. Id. at $741-42$.

40. Id. at 742 .

41. Id.

42. Id. at $742-43$.

43. Id at 743 .

44. Id. at 734 .

45. Saperia, supra note 31 , at 185.

46. Interestingly, although New Hebrides remains a textbook example of a colonial condominium, "condominium" was not mentioned in any of the constitutional documents establishing the condominium. See O'Connell, supra note 1, at 78 .

47. Id. at 71 .

48. Bantz, supra note 7 , at 120 . 
archipelago. ${ }^{49}$ By assuming joint jurisdiction over the islands, France and Great Britain ruled over French and British nationals individually but ruled over the indigenous population together. ${ }^{50}$ The treaty pledged that France and Great Britain would not intervene separately in New Hebrides, but only together, with their paramount rights combined to guard against the potential arrival of a third power. ${ }^{51}$ The New Hebrides judicial branch also reflected this joint rule, with the tripaneled judiciary comprised of one French judge, one British judge, and one neutral third member. ${ }^{52}$ Financially, the tax revenue was divided equally between France and Great Britain, with each state responsible for the expense of their own administration. ${ }^{53}$ However, the French and British governments paid for all essential government services jointly. ${ }^{54}$

The executive branch of New Hebrides was co-governed by the British Resident Commissioner and French Resident Commissioner, both of whom operated collectively in determining all major resolutions. ${ }^{55}$ These laws would be enforced by the New Hebrides police force, which was divided into two separate legions of British and French policemen, with native officers serving on both forces. ${ }^{56}$ Each police force was responsible for policing the actions of their own nationals, with the cost of maintaining the force paid by each force's respective national government. ${ }^{57}$ Each police force reported to the two national Commandants, who in turn served under their country's respective National Commissioner. ${ }^{58}$ Although the New Hebrides condominium was able to endure for over seven decades, Britain's waning interest in the island chain in the latter half of the twentieth century eventually precipitated the termination of the condominium in 1979.59 With the formation of the sovereign nation of Vantu shortly thereafter, ${ }^{60}$ New Hebrides marked the last colonial condominium to achieve independence. ${ }^{61}$

49. Samuels, supra note 2, at 737 .

50. Id. at 738 .

51. Bantz, supra note 7, at 121.

52. Samuels, supra note 2 , at 738 .

53. Id.

54. Id.

55. Id at 738-39.

56. Id. at 739 .

57. Id.

58. Id. at 739 .

59. Bantz, supra note 7 , at 122 .

60. Saperia, supra note 31 , at 185 .

61. Samuels, supra note 2, at 735 . 


\section{THE HISTORICAL EVOLUTION OF THE CONDOMINIUM}

Employing the condominium solution as a resolution to a disputed territory between two sovereign states has ancient origins, with the first recorded example of a condominium occurring in the thirteenth century BC. 62 In the wake of a intensely brutal battle between the warring empires of Egypt and Hatti in $1294 \mathrm{BC}$ over a territory in modern day Turkey, the Egyptian Pharaoh Ramses II and the Hittite King Hattisulus III entered a treaty that not only pledged peaceful relations between the belligerent parties, but also agreed to jointly cooperate in controlling unruly subjects in Syria. ${ }^{63}$ Although little else is known about this ancient treaty, ${ }^{64}$ it remains the first example of a novel and revolutionary concept within the province of international relations: two states having joint sovereignty over a disputed territory. ${ }^{65}$

Although examples of condominiums on the international stage have existed de facto since the time of the Ancient Egyptians, the condominium, as a defined legal concept within international law, has its origins in Roman civil law.66 Founded upon the Roman civil law foundation of communion pro indivisio (undivided joint property), the condominium property model was embraced by Italian scholars in the Middle Ages and was gradually applied to international law as a model for joint sovereignty and administration over a territory. ${ }^{67}$ Italian scholars of civil law coined the word "condimius" to define this new territorial concept, with the first written references to it appearing in the fourteenth and fifteenth centuries. ${ }^{68}$ These Medieval academics slowly spread international law and, with it, the concept of condominium to the Germanic States and the rest of Western Europe. ${ }^{69}$ Consequently, condominiums appeared in the later stages of the Holy Roman Empire, where they were employed to designate the joint exercise of two sovereign princes' territorial rights over specific towns and lands. ${ }^{70}$ Viewed as a co-proprietorship or joint dominum, the term was employed as a way of articulating feudal occupation of estates. ${ }^{71}$

62. Id. at 732 .

63. Id. at $732-33$.

64. Id. at 733 n. 26.

65. See generally id. at 732-33.

66. Id. at 733 .

67. Id.

68. P. Van Warmelo, Aspects of Joint Ownership in Roman Law, 25 TIJDSCHRIFT VooR RECHTSGESCHIEDENIS 123, 125 n.1 (1957).

69. See generally Samuels, supra note 2, at 733 .

70. O'Connell, supra note 1 , at 77.

71. Id. 
The nineteenth and early twentieth centuries would witness a proliferation of condominiums on the international stage, as resourcehungry and land-hungry European colonial powers were often pitted against one another over a disputed territory. ${ }^{72}$ Becoming a modus vivendi between warring powers and featured prominently in the Treaty of Vienna at the conclusion of the Napoleonic Wars, the condominium was perceived as a temporary solution to maintain the precarious balance of power in Europe in the modern age. ${ }^{73}$ Notable condominiums enacted during this period included New Hebrides (1906-1980) between France and Great Britain; ${ }^{74}$ Moresnet (1816-1819) between Prussia and the Netherlands; ${ }^{75}$ Schleswig-Holstein (1855-1856) between Prussian and Austria; ${ }^{76}$ Samoa (1889-1899) between Germany, Great Britain, and the United States; 77 and lastly Sudan (1898-1955) between Great Britain and Egypt. ${ }^{78}$

Despite its regular employment during the nineteenth and early twentieth centuries, the condominium solution faded into obscurity on the international stage in the latter half of the twentieth century.79 Critics of the condominium solution would champion the Westphalian notion of a state, ${ }^{80}$ which held the principle of sovereignty to be paramount, 81 an "illimitable, indivisible, and exclusive form of public power." 82 Labeling the condominium solution as a "historical relic," 83

72. See generally id. at 77.78.

73. Samuels, supra note 2, at 733-34.

74. See generally Bantz, supra note 7, at 119-22.

75. See generally id. at 109.11.

76. See generally id. at $122-23$.

77. Samuels, supra note 2, at 745-47.

78. Id. at $752-53$.

79. Id. at 734. The lack of the use of the condominium solution in the latter half of the twentieth century could also be partly attributed to the decolonization by Europe and Asia following the Second World War.

80. The Westphalian Model was named after the eponymous Treaty of Westphalia, a European peace accord drafted at the conclusion of the Thirty Years War in 1648. See David Held et. al, Global Transformations: Politics, Economics and Culture 37 (1999) (noting of the Westphalian paradigm, "The model depicts the development of a world order consisting of territorial, sovereign states in which there is no supreme authority; states settle their differences privately and by force if necessary; they engaged in diplomatic relations but otherwise there is minimal cooperation; they seek to place their own (national) interest above all others; and they accept the logic of the principle of effectiveness, that is, the principle that might eventually make right in the international world-appropriation becomes legitimation.")

81. Josh Delbrück, Structural Changes in the International System and its Legal Order: International Law in the Era of Globalization, 1 SZIER 1, 4 (2001).

82. DAVId HELd \& ANTHONY MCGREW, Globalization/ANTI-GLOBaLIZATION: BEyond THE GREAT DIVIDE 212 (2nd ed. 2007).

83. Samuels, supra note 2, at 730 . 
critics pointed to the fact that the condominium solution was usually enacted as a temporary or emergency solution and a measure of last resort.84 The critics further argued that this transitory nature would make it difficult to establish a permanent solution in a condominium territory. ${ }^{85}$ Moreover, critics argued that if two states were unable to reach a peaceful compromise over a disputed territory, it was difficult to imagine they would be able to cooperate in the daily administration of. the disputed territory. ${ }^{86}$ As a consequence of these criticisms and the increasing emphasis on the absolute sovereignty of the state, the western European country of Andorra remains one of the only functioning political condominiums in the world. ${ }^{87}$

\section{THE History OF ANDORRA AND THE RISE OF THE CONDOMINIUM SOLUTION}

Located on a sliver of land wedged between Spain and France, ${ }^{88}$ the territory of Andorra was fiercely fought over in the early Middle Ages between the French Counts of Foix and the Spanish Bishops of Urgell. ${ }^{89}$ Although the origins of this dispute are somewhat opaque, historians largely agree that it began when Louis the Pious, son of Charlemagne, bestowed Andorra to the Count of Urgell in 819.90 The Count of Urgell later traded Andorra to the Bishop of Urgell in exchange for other adjacent fiefdoms. ${ }^{91}$ However, fearing that the bellicose Count of Urgell would attempt to retake the traded land by force, the Bishop of Urgell, in the eleventh century, granted Andorra in fief to the powerful Caboet family to bolster military protection in the area. ${ }^{92}$ Consequently, these feudal privileges descended by marriage to the French Count of Foix in

84. Id.

85. Id. at 729 .

86. Id. at 730 .

87. See Jacco Bomhoff, The Reach of Rights: "The Foreign" and "The Private" in Conflict-of-Laws, State-Action, and Fundamental-Rights Cases With Foreign Elements, 71 LAW \& CONTEMP. PROBS. 39, 62 n.137 (2002).

88. Andorra's border with France was codified in the Treaty of Corbeil in 1258, and Andorra's border with Spain was codified in an 1863 treaty. JORRI DUURSMA, Fragmentation and the InTERnational Relations of Micro-States: SElFDETERMINATION AND STATEHOOD 316 n.1 (1996).

89. These disputes had resulted in "the slaughter of men, the destruction of castles, the mutilation of men's bodies, and many other atrocities and almost unspeakable evils." Derwent Whittlesey, Andorra's Autonomy, 6 J. MODERN HISTORY 147, 149 (1934) (quoting the Acte de Paréage).

90. DUURSMA, supra note 88, at 317.

91. See P. ChristiaAn Klieger, The Microstates of Europe: Designer Nations in A POST-MODERN WORLD 29 (2013).

92. Id. 
1208.93 These Counts of Foix soon bridled against the lordship of the Urgellian Bishop, sparking decades of warfare over control of Andorra. ${ }^{94}$

To resolve this ongoing dispute, both the French Count and Spanish Bishop in 1278 agreed to a document known as the Acte de Paréage:95 this treaty articulated that the French Counts of Foix and the Spanish Bishop of Urgell would cease their belligerence, ${ }^{96}$ pledge to not incorporate Andorra into their respective territories, ${ }^{97}$ and be granted co-equal sovereignty over Andorra that they would administer in concert. ${ }^{98}$ Under the aforementioned treaty, the French Counts of Foix and the Bishop of Urgell would also each select an agent (Viguier) to represent them in Andorra. ${ }^{99}$ Moreover, under the Act de Paréage, both parties would receive fief payments (qüèstia) ${ }^{100}$ from Andorran vassals in alternating years, as well as be given the ability to recruit soldiers from the general Andorran populace. ${ }^{101}$ However, although given the right of conscription, the co-sovereigns were proscribed under the Act from employing Andorran soldiers against the other. ${ }^{102}$ Moreover, under the Act, the co-sovereigns were each given the power to administer justice jointly through bipartite civil justice panels (battles), with one judge appointed by the Bishop and one appointed by the French co. sovereign. ${ }^{103}$

93. DUURSMA, supra note 88 , at 317.

94. Id. The dispute was further compounded by the fact that the Counts of Foix defended the Cathars, an anti-Romanist movement labeled as heretical by the Catholic Church. For more information on this, see generally Klieger supra note 91, at 29-30.

95. This treaty came about through the intervention of the Bishop of Valencia, who helped to mediate the accord. See DUURSMA supra note 88, at 317. Moreover, this treaty was given Royal sanction by the King of Aragon as well as Papal approval by Pope Martin IV in 1282. Joseph H. Rogatnick, Little States in a World of Powers: A Study of the Conduct of Foreign Affairs by Andorra, Liechtenstein, Monaco, and San Marino 28 (May 1976) (unpublished Ph.D. dissertation, University of Pennsylvania) (on file with Indiana University Maurer School of Law).

96. Whittlesey, supra note 89 , at 152-53.

97. Marc Maresceau, The Relations Between the EU and Andorra, in LAW AND Practice of EU External Relations: Salient Features of a Changing Landscape 270, 273 (Alan Dashwood \& Marc Maresceau eds., 2008).

98. Rogatnick, supra note 95, at 28. Although the Act de Pareage stipulated that the Count of Foix would remain a vassal of the Bishop in perpetuity, the Count ignored this provision and in 1299 unilaterally repealed this portion of the act. Id. at 29 .

99. Barry Taylor, Andorra, in 167 WORLD BIBLIOGRAPHICAL SERIES xiii, xiii (1993).

100. DUURSMA, supra note 88, at 318. As of 1996, Andorrans still honored this ancient act by giving the Bishop of Urgell 450 pesetas and the French President 960 francs. Id. at 318 n.15.

101. Rogatnick, supra note 95 , at 28-29.

102. Id. at 29.

103. Id. at 28 . 
However, as feudalism was slowly supplanted by centralized nationstates in the early modern era, the successors of the Andorran suzerainty became enveloped into larger nation-states. ${ }^{104}$ Accordingly, in 1589, the French Counts transferred the right to the Andorran territory to the French King, ${ }^{105}$ with this right later transferred to the French State in 1870.106 Although the Bishopric of Urgell was later merged into Catalonia and then into Spain, ${ }^{107}$ the Bishop of Urgell has never transferred his joint sovereign right over Andorra. 108

Although the condominium that the Act de Paréage had established remained largely undisturbed for over six centuries, ${ }^{109}$ the nineteenth and twentieth centuries brought fundamental changes to co-sovereignty in Andorra. As the modernizing forces circulating through Europe in the middle of the nineteenth century found their way into Andorra, they precipitated a split of the Andorran populace between a conservative pro-condominium party and a liberal party that advocated for more local autonomy in governance. ${ }^{110}$ To mollify the feuding factions within the country, in 1855 the Bishop of Urgell unilaterally promulgated an edict granting greater autonomy to Andorrans. ${ }^{111}$ Calling for a "New Reform," the edict ceded to Andorrans the right to manage internal public services. ${ }^{112}$ To accomplish this end, the edict established a democratically elected deliberative body, ${ }^{113}$ known as Consell General de

104. Whittlesey, supra note 89, at 153.

105. The French Counts' hereditary rights to lordship over Andorra would descend through marriage to Henry of Navarre, who became King of France in 1589. See LEwIS GASTON LEARY, ANDORRA: THE HIDDEN REPUBLIC 28 (1912).

106. See Carl Waldman \& Catherine Mason, Encyclopedia of European Peoples 21 (2006).

107. Whittlesey, supra note 89 , at 153

108. Saperia, supra note 31 , at 184 . However, with the increasing centralization of power under of the French co-sovereign, the Bishop of Urgell sought to elevate his title to achieve parity with his Galician co-ruler; consequently, in 1633 the Bishop cavalierly declared himself "Sovereign Prince of the Valleys of Andorra." Rogatnick, supra note 95, at 30 .

109. Id. at 31. Indeed, as a visitor to Andorra observed of Andorra in 1900, "Andorra has kept its medieval usages and institutions almost unchanged." KENNETH POMERANZ \& Steven Topik, The World that Trade Created: Society, Culture, and the World ECONOMY 213 (2nd ed. 2006).

110. Rogatnick, supra note 95, at 32 . These modernizing forces that advocated for liberal democracy were part of the "first wave of democratization," a movement that began in the early nineteenth century and lasted until the mid-1920s. HELD ET. AL., supra note 80 , at 46 .

111. Rogatnick, supra note 95 , at 32-33.

112. Id. at 33 .

113. Id. It should be noted that until 1933, only male heads of households were granted suffrage. Thomas EcCardt, SECrets of THE SEven SMallest States of EuRope: 
les Valls d'Andorra (Council General). ${ }^{114}$ Consisting of twenty-four members (four representatives from each of the six parishes of Andorra), ${ }^{115}$ the Council General administered internal public services; these services included maintaining infrastructure, taxing imports, judging appeals made by municipal and sub-municipal agencies, and issuing passports. ${ }^{116}$ However, despite the newly expanded power of the legislature, any decision made by the Council General would still be subject to veto, singly or collectively, by the co-sovereigns. ${ }^{117}$ The French co-sovereign, under pressure from forces calling for greater selfdetermination in the governance of Andorra, acquiesced to signing this edict in 1868.118

Even greater alterations to the Andorran condominium occurred at the end of the twentieth century, as calls for self-determination by the Andorran populace grew progressively louder. Faced with problems caused by Andorra's nebulous legal order, the lack of codified laws, and the ambiguity of delineation between different governmental organs, the General Council in 1975 penned a letter to the co-sovereigns requesting a reexamination of Andorran institutions. ${ }^{119}$ The cosovereigns granted the request, initiating an eighteen-year process of internal governmental reforms. ${ }^{120}$ Part of these reforms was the establishment in 1981 of an Executive Council, the predecessor to the modern Andorran government. ${ }^{121}$ The head of this new established Executive Council announced in 1990 his intention of promulgating an Andorran Constitution, creating a tripartite commission-comprised of two co-sovereigns as well as representatives of the General Counsel-to draft the document. ${ }^{122}$ Unanimously approved by the General Counsel

andorRa, Liechtenstein, Luxembourg, Malta, Monaco, San Marino and Vatican CITY 154 (2005). Women were granted the ballot in Andorra in 1970. Id. at 170.

114. Rogatnick, supra note 95, at 33 . However, Andorra had a quasi-deliberative body, which predated the Council General, called the Council of Land; established in 1419, only the heads of important families were granted membership. See ECCARDT, supra note 113, at 152 .

115. Rogatnick, supra note 95 , at 51.

116. Id. at 50.

117. Id. at 52 .

118. Id. at 33 .

119. DUURSMA, supra note 88 , at 320 . Some writers have speculated that increased calls for governmental reform were precipitated by the booming Andorran economy, resultant from tourism and low taxes, as an increasingly affluent Andorran populace demanded greater governmental autonomy. See Maresceau, supra note 97, at 275.

120. DUURSMA, supra note 88 , at 320 .

121. Id. at 321 .

122. Id. Many of the neighboring European states also vocally championed an Andorran constitution in order to ensure codified rights for non-citizens and guest workers. See KLIEGER, supra note 91, at 34. Indeed, non-citizens comprise $75 \%$ of Andorra's population. 
and endorsed by 74.2 percent of Andorran voters, the Andorran Constitution became effective on May 4, 1993.123

\section{THE CO-PRINCIPALITY OF ANDORRA AND THE MODERN ANDORRAN CONSTITUTION}

Enacted over seven centuries after the Act de Paréage established joint rule over Andorra, the Andorran Constitution would finally codify the condominium solution within article forty-three and forty-four. ${ }^{124}$ Established as a parliamentary principality, ${ }^{125}$ the Andorran Charter vests the Spanish Bishop of Urgell and the French State (personified by the French President) as co-princes, jointly and divisibly Cap de l'Estat (Chief of Staff) of Andorra. ${ }^{126}$ The Constitution explicitly articulates that the powers between the two co-sovereigns are equal, 127 vesting them with "highest representation."128 Regularly informed of the affairs of the state and immune from lawsuit, ${ }^{129}$ the co-princes arbitrate and moderate the functioning of public authorities. ${ }^{130}$ Interestingly, because the French Constitution makes no reference to the president's responsibility as co-prince of Andorra, there is no legal requirement that the French president, as co-prince, make any attempt to conform his Andorran policies to French law. ${ }^{131}$ Additionally, in the event of a vacancy of one of the co-princes, the Constitution stipulates that power be substituted with the laws of their respective organizations (i.e., the French Constitution or Canon Law). ${ }^{132}$

Moreover, the co-princes appoint the Cap de Govern (Executive Council President) following his or her election by the Andorran

Guy Olivier Faure \& Patrick Klaousen, Andorra-European Community Trade Agreement Negotiations, 1979-1987, in POWER AND NEgotiation 107, 110 (William Zartman \& Jeffery Z. Rubin eds., 2000).

123. DUURSMA, supra note 88 , at 321 .

124. CONSTITUCIÓ D'ANDORRA, 28 April 1993, art. 43-44. Indeed, even the state motto seems to implicitly champion the condominium solution, trumpeting, "virtus unita fortiori" or "A United Action is Much Stronger." ECCARDT, supra note 113, at 164. Prior to the promulgation of the Andorran constitution, the rights of Andorrans were based on custom, tradition, and established practices. Rogatnick, supra note 95, at 47.

125. CONSTITUCIÓ D'ANDORRA, 28 April 1993, art. 1.

126. Id . at art. 43 .

127. Id.

128. Id.

129. Id. at art. 44 .

130. Id.

131. DuURSMA, supra note 88 , at 345 . Moreover, due to a treaty signed by both France and Andorra, France may be prohibited from placing the French co-Prince in a position that could jeopardize Andorran independence. Id.

132. CONSTITUCIÓ D'ANDORRA, 28 April 1993, art. 49. 
Parliament. ${ }^{133}$ Like the Viguer in medieval times, each co-prince appoints an agent to represent him in Andorra. ${ }^{134}$ In a shift away from the cost of the Andorran administration being indemnified through the French and Spanish governments, the annual budget of Andorra now allocates an equal amount to each of the co-princes commensurate with the functioning of their services. ${ }^{135}$ The co-princes also have the power to initiate any revision to the Constitution. ${ }^{136}$ Additionally, the coprinces have the power to veto any proposed law, treaty, or governmental appointment. ${ }^{137}$ Legislatively, the Andorran State has a great degree of autonomy, having a unicameral legislature with members elected by direct popular vote. ${ }^{138}$ In addition to legislative power, the General Council represents the Andorran people, authorizes the state budget, and dictates the political actions of government.139 However, as executives, signature by the co-princes are required to promulgate any new law. 140

The Andorran Constitution also introduced a number of reforms to the judicial branch of Andorra. Instead of justice being dispensed in the name of the co-princes, it is now administered in the name of the Andorran people.141 More importantly, judges are no longer appointed by the co-princes in the form of battles, but are instead appointed by the newly constituted Supreme Council of Justice. ${ }^{142}$ This High Court of Justice, in turn, is composed of five members: one member appointed by each of the co-princes, one by the General Council, one by the Head of the Government, and one by the judges. ${ }^{143}$ The Constitutional Tribunal, which has advisory jurisdiction, is composed of four judges: one appointed by each of the co-princes, and two appointed by the General Council.

Although there have been substantial changes to the legislature and judiciary, the external relations of Andorra still remain in the province

133. Id. at art. 73 .

134. Id. at art. 48.

135. Id. at art. 47. This constitutional provision changes the funding for the co-princes; prior to the Constitution's codification, the French President and the Bishop of Urgell were indemnified for their expenses from the French and Spanish government respectively. DUURSMA, supra note 88 , at 322 .

136. CONSTITUCió D'ANDORRA, 28 April 1993, art. 105.

137. Thomas D. Grant, Between Diversity and Disorder: A Review of Jorri C. Duursma, Fragmentation and the International Relations of Micro-States: Self-Determination and Statehood, 12 AM. U. INT'L L. REV. 629,669 (1997).

138. See generally CONSTITUCIÓ D'ANDORRA, 28 April 1993, tit. IV.

139. Id. at art. 50.

140. Grant, supra note 137, at 669.

141. CONSTITUCIÓ D'ANDORRA, 28 April 1993, art. $85, \S 1$.

142. Id. at art. $89, \S 3$.

143. Id. at $\$ 2$. 
of the co-princes. As Chief of Staff, the co-princes are vested with establishing diplomatic relations with other states and with entering foreign treaties. ${ }^{144}$ Indeed, under article 44 of the Andorra Constitution, the document entrusts the co-princes with the sole authority to maintain the international personality, noting, "They express the consent of the Andorran State in honoring its international obligations, in accordance with the Constitution." 145

Although the Constitution stipulates that international relations are still conducted through the co-princes, the subsequent Treaty of Vicinage between Spain, France, and Andorra has qualified the extent of this power. Enacted in 1993, the treaty codifies Andorra's ability to establish an international personality, with the signatories expressly recognizing Andorra as a sovereign state. ${ }^{146}$ Under this treaty, France and Spain may not impede Andorra's participation in international meetings and organization. ${ }^{147}$ However, Andorra's autonomy in international diplomacy is encumbered in two ways: first, Andorra must adhere to international conventions to which France or Spain is also a party. ${ }^{148}$ Secondly, Andorra must respect the "fundamental interest" of both Spain and France and must to cooperate in the settlement of any issues that concern such fundamental interests. ${ }^{149}$ Despite these two restrictions, by negotiating with Andorra as a sovereign state, France and Spain have both implicitly and explicitly recognized and sanctioned Andorra's international personality on the world stage. Indeed, both Spain and France have recognized the independence of Andorra, with both states establishing diplomatic relations with Andorra in 1993.150 However, despite the fact that Andorra gained admission to the United Nations in 1993 and the Council of Europe in 1994, neither body has held discussions on whether Andorra constitutes an independent state. ${ }^{151}$

144. KuIEGER, supra note 91 , at 34 . It should be noted that although the president of the French Republic acting in his capacity as co-prince of Andorra signs a treaty on behalf of Andorra, it does not also bind France to that treaty. Stephen Eliot Smith, Uncharted Waters: Has the Cook Islands Become Eligible for Membership in the United Nations, 8 N.Z. J. PUB. \& INT'L L. 169, 208 (2010).

145. CONSTITUCIÓ D'ANDORRA, 28 April 1993, art. 44.

146. DUURSMA, supra note 88 , at 335 . Interestingly, because the French constitution did not consider the prospect of the president being the head of two separate states simultaneously, France was initially forced to delay recognition of Andorra's statehood. Faure \& Klaousen, supra note 122 , at 125 n.1.

147. DUURSMA, supra note 88 , at 336 .

148. Id.

149. Id.

150. Id. at 338 .

151. Grant, supra note 137 , at 671. 


\section{EXPLANATIONS FOR WHY THE CONDOMINIUM SOLUTION IN ANDORRA HAS REMAINED}

Andorra remains an anomaly in the political realm, indefatigably continuing the condominium solution over the centuries while most other condominiums have failed within a few years. Andorra's enduring condominium solution therefore begs the question of why a solution that is largely regarded as a temporary fix has had such atypical longevity. An initial explanation on the endurance of Andorra's condominium solution is that Andorra is not the anomaly of the condominium solution, as Andorra is not in fact a condominium per se: indeed, where other condominiums have traditionally involved two sovereign states, Andorra involves one sovereign state (France), while the other co-ruler is embodied in the Bishop of Urgell, an ecclesiastical leader not directly affiliated with Spain. ${ }^{152}$ This point was highlighted in the case of Drozd and Janousek v. France and Spain, where a European tribunal held that Andorra was not a Franco-Spanish condominium. ${ }^{153}$ Unlike condominiums per se between two actual states, which have historically only lasted for a few decades, Andorra arguably boasts only one true state and, therefore, really only one state authority: France. As Commissaire du Gouvernement Odent noted in Radio Andorre, "Since the mitre of Urgell, the other suzerain, does not have any international existence, it necessarily ensues that France, and France alone, bears international responsibility for the Valleys of Andorra."154 Moreover,

152. Saperia, supra, note 31 , at 188 . The argument can be made, however, that because the Holy See-the governing body of the Vatican City-State-appoints the Bishop of Urgell, the Bishop is actually a representative for the Vatican City-State, thereby satisfying the classic definition of joint sovereignty by two states. See Grant, supra note 137, at 670-71. However, the counterargument is that the Holy See exercises no continuing authority over the Bishop as co-prince, but instead the Holy See only has the ability to appoint and elevate the Bishop within the Church hierarchy. Id. at $670 \mathrm{n} .248$. Additionally, some have argued that although the Bishop of Urgell is institutionally separate from Spain, due to the Bishop of Urgell being a Spanish citizen residing in Spain, the Spanish Bishop acts as a de facto proxy for Spain. See Faure \& Klaousen, supra note 122 , at 111 .

153. The case involved two Andorran thieves who were tried and convicted in an Andorran court. As Andorra had no prison facilities, the defendants were sent to France where they subsequently filed suit alleging their trial violated the European Convention on Human Rights, signed by both France and Spain. The court held that there was no jurisdiction to hear the claim, as Andorra had not been a signatory to the convention and was not a Franco-Spanish condominium. Moreover, the court found that although the coprinces had appointed Andorran judges together, they failed to act in their national capacity as French and Spanish judges and were therefore not subject to the supervision of France or Spain. Barbara Miltner, Revisiting Extraterritoriality After Al-Skeini: The ECHR and Its Lessons, 33 MiCH. J. INT'L L. 693, 734 (2012).

154. Bantz, supra note 7 , at 105 . 
because France remains the only state within the Andorran condominium, the condominium does not face the same problems of nationalistic hubris and jingoistic foreign policy that can exacerbate and escalate tension over a disputed territory between two competing states. Additionally, some writers have also speculated that the local Andorran's adroit political diplomacy of pitting one co-sovereign against the other-thereby maintaining a balance of power-has ensured the condominium's longevity. ${ }^{155}$

A second theory as to why the condominium solution in Andorra has continued to endure is because Andorra has few natural resources, ${ }^{156}$ little arable land, ${ }^{157}$ and, due to its proximity in the Pyrenees Mountains, is highly isolated.158 Consequently, these negative characteristics have rendered Andorra undesirable to its neighbors. Unlike the disputed territory of Kashmir that has been partly fought over by both Pakistan and India for being the location for the start of the Indus River, Andorra boasts few desirable resources for the condominium members. Indeed, it is telling of Andorra's relative insignificance to neighboring states that, since the Acte de Paréage in 1278, Andorra's condominium has only once been truly in jeopardy, ${ }^{159}$ remaining unmarred by war for the last seven centuries. ${ }^{160}$

155. See Maresceau, supra note 97, at 273-74. Indeed, Andorra has a long tradition of strict neutrality, with a Manuel Digest in 1748 promulgating the aphorism that Andorra should always remain neutral in case of war between France and Spain. DUURSMA, supra note 88 , at 335 .

156. See POMERANZ \& TOPIK, supra note 109 , at 213.

157. Due to the mountains terrain of Andorra, only about $4 \%$ of the land is arable. Rogatnick, supra note 95 , at 18 . Indeed, in 1990, this amounted to 1,000 hectares, upon which the staple crops of tobacco and potatoes are grown. See Taylor, supra note 99, at xiv.

158. Due to its isolation, travelling to Andorra can pose a challenge: it lacks an airport or train station, and the nearest city of Toulouse is over a two-hour drive away. Pat Thompson, Why Andorrans Live Longer than Everyone Else, CNN (April 23, 2009, 7:16 PM), http://www.cnn.com/2009/HEALTH/04/23/andorra.life.expectancy/index.html. As the Andorran President commented to the U.N. assembly on Andorra's isolation from the rest of Europe, "less than a century ago it was only possible to arrive in Andorra on horse." U.N. GAOR, 58th Sess., 11th plen. mtg. at 17, U.N. Doc. A/58/PV.11 (Sept. 25, 2003). Indeed, the first roadway into Andorra was not constructed until 1913. Rogatnick, supra note 95, at 22. However, interestingly enough, although Andorra's relative isolation seems to be an undesirable characteristic to its neighbors, its rustic and remote lifestyle has resulted in its inhabitants boasting one of the highest life expectancies in the world. See Thompson, supra note 158.

159. The Andorran condominium was only once placed in jeopardy during the French Revolution in 1793: as the French revolutionaries refused to accept the quiesta because of its feudal origin, the French co-sovereign technically temporarily suspended its tributary relationship with Andorra. Rogatnick, supra note 95, at 30 . However, Napoleon, ever the lover of tiny states, reinstated the co-sovereignty in 1806. Id.

160. POMERANZ \& TOPIK, supra note 109 , at 213. 
A third and final theory of why the condominium solution has succeeded in Andorra where it has failed in many other disputed territories is its lack of cultural influence and power. ${ }^{161}$ Unlike the disputed territory of Gaza that is desired and claimed by both the Palestinians and Israelis due to its rich cultural, historical, and religious heritage, Andorra has historically been relatively remote and unimportant in international affairs and has not held enough real political, religious, or historical significance over either France or Spain to warrant precipitating a dispute. ${ }^{162}$

\section{The FUtURE OF THE CONDOMINIUM SOLUTION AS A LASTING RESOLUTION TO DISPUTED TERRITORIES}

In spite of the absence of condominium solutions on the world stage today, excepting Andorra, the possibility of viable similar political arrangements in international disputes is not foreclosed. As Hersch Lauterpacht, a leading international relations scholar, noted on the viability of condominiums, "There is nothing in the legal theory or in the nature of sovereignty to render impossible a permanent and agreed division of sovereignty as suggested by the nature of a condominium." 163 Indeed, in the last century, the stress on the paramount importance of absolute sovereignty in international relations has been deemphasized, as states have begun reevaluating their traditional Westphalian conceptions of sovereignty.

This reassessment of the Westphalian paradigm began in the early nineteenth and twentieth centuries, as industrial and technological revolutions, coupled with the rapid growth of international markets, led states to create new international mechanisms to govern global affairs. ${ }^{164}$ To cope with the novel challenges of an increasingly interconnected and interdependent world, European states established intergovernmental collective regimes such as the International Telegraph Union and the Universal Postal Union to administer and regulate interstate territory. ${ }^{165}$ This movement away from the Westphalian model toward a collective governmental model accelerated during the early twentieth century. In the wake of the First and Second World Wars the staggering devastation precipitated an increasing acceptance that the traditional "balance of power" paradigm in international governance was inadequate to contend with the rapidly

161. See Saperia, supra note 31, at 188.

162. Id.

163. Samuels, supra note 2 , at 728 .

164. See Delbrück, supra note 81 , at 4.

165. Id. 
changing political landscape.166 Indeed, following the unprecedented devastation wrought by the Second World War, states became increasingly cognizant that, if the most extreme crimes against humanity were to be proscribed, a new governance paradigm would be required. ${ }^{167}$

This paradigm would manifest itself at the end of World War II with the creation of the United Nations. Established for the purpose of collectively regulating and administering an international territory, the United Nations was constituted as a community of states with equal voting rights through a General assembly. ${ }^{168}$ Under its Charter, the United Nations was vested with the responsibility for maintaining international peace and security, endowing the U.N. Security Council with the ability to intercede in the internal affairs of Member States. Significantly, the United Nations Charter also expressly proscribed any Member States from using or threatening to use force. ${ }^{169}$ By prohibiting a state's liberium ius ad bellum or ability to go to war-a right held to be a fundamental tenet of the Westphalian model of sovereignty-it marked a tectonic shift in the concept of sovereignty on the world stage. 170 More importantly, as the United Nations continues to present an alternative model that challenges the Westphalian paradigm of global governance and traditional geopolitics, it illustrates the viability of an intergovernmental community governed and administered through collective decision-making. ${ }^{171}$

Nowhere has the practicability of states pooling their sovereignty to constitute an international community been more exemplified than in the European Union. First created in embryonic form by six European states under the name of the European Community in 1952, it was established as an international mechanism to create a single market and supranational authority over the regulation of coal and steel in Member States. ${ }^{172}$ Six year later, the Rome Treaties established the

166. See HELD ET AL., supra note 80, at 62 .

167. Id.

168. Id. at 63. Admittedly, however, there is a distinct difference between the United Nations and the condominium solution; although the UN has ostensibly equal voting rights, some states remain more equal than others, with powerful nations afforded a veto power on any legislation via the UN Security Council. Id.

169. See Delbrück, supra note 81 , at 7.

170. Id.

171. See HELD ET AL., supra note 80, at 65. Indeed, the UN has aided in the development of collective regulation of international public goods such as "international air traffic control, telecommunication, control of contagious diseases, humanitarian relief for refugees and victims of natural disasters and the protection of the environmental commons." Id.

172. Kristin Archick, Cong. Research Serv., RS21344, European Union ENLARGEMENT 2 (2013). 
European Economic Community, an international organization that extended this common market idea to all economic sectors, ${ }^{173}$ as well as creating the European Energy Community to monitor the use of nuclear energy among the Member States. In 1967, these three communities would become consolidated into one organization, collectively becoming the European Community.174 Over the successive decades, more European states would join the European Community, voluntarily ceding part of their sovereignty to share in the political and economic benefits flowing from joint governance. To achieve even greater political and economic integration among its Member States, in November of 1993 the Maastricht Treaty was enacted, establishing the current European Union. ${ }^{175}$

As the European Union is a network of states that have pooled their own sovereignty to jointly govern a territory, ${ }^{176}$ it stands as testament to the viability of the condominium solution. In David Held's description of the voluntary transfer of sovereignty from the European Member State to the European Union, analogies can immediately be drawn to the condominium solution: "By creating a community of unlimited duration, having its own institutions ... and, more particularly, real powers stemming from a limitation of sovereignty or a transfer of powers from the state to the community, the member states have limited their sovereign rights." 177 With European Member States voluntarily joining an international collective and pooling their sovereignty to co-govern a territory, the European Union can be conceptualized as a macro-version of the condominium solution on a global scale. Moreover, far from weakening the individual states that have joined in this European Community by voluntarily ceding some of their sovereignty, the European Union has instead served to strengthen its constituent states against the power of the United States and an ascending China. ${ }^{178}$

In a globalized world that is increasingly interconnected and interdependent, the latter half of the twentieth century has arguably witnessed the emergence of a post-Westphalian order. ${ }^{179}$ Ironically, it is the same European states that helped to promote and cement the notion of absolute sovereignty as the chief characteristic of the state in the treaty of Westphalia that have begun to dismantle this principle through their voluntary membership in international governmental

173. Id.

174. Id.

175. Id.

176. See HELD ET AL., supra note 80 , at 74 .

177. Id. at 74 .

178. Id. at 74 .

179. Id. at 441 . 
collectives. Indeed, with the rise of international collectives such as the United Nations and the European Union, legal scholars are redefining sovereignty and autonomy to reflect the new post-Westphalian world order. ${ }^{180}$ Accordingly, international law has begun to acknowledge this tectonic shift in the notion of sovereignty, with a new proposal of sovereignty defined as "membership in reasonably good standing in the regimes that make up the substance of international life ... Sovereignty, in the end, is status-the vindication of the states existence as a member of the international system." 181 Truly, in this collectivized age of the United Nations and the European Union, it is not the condominium solution, with its idea of an international community of pooled sovereignty, that is the "historical relic"; 182 instead, it is the critics of the condominium solution-those who obstinately cling to the outmoded Westphalian notion of sovereignty in the face of a fundamentally changed global landscape - who remain the artifacts of a bygone era.

\section{CONCLUSION}

Arising as a solution to a war over a disputed territory over three millennia ago, the popularity of the condominium solution has ebbed and flowed throughout the centuries. Revived as a legal concept of joint rule in the nineteenth century as a way for colonial powers to settle disputes over territory, in the latter half of the twentieth century it would once again fall out of vogue in political circles. Denounced by some critics as being antithetical to the conception of the modern state due to the Westphalian primacy of absolute sovereignty, the condominium solution has all but disappeared from the modern political lexicon. Branded as a modern anachronism and a relic of the feudal era, critics have pointed to what they see as the condominium solution's inherently temporary nature, thereby foreclosing the possibility of employing it as permanent resolution to a disputed territory.

Yet, despite the torrent of criticism the condominium solution has received from political and legal scholars, the condominium has

180. See Delbrück, supra note 81 , at 20.

181. Id.

182. Interestingly, some scholars do not view "medieval" as a pejorative term; indeed, Bull argues that in a global order characterized by overlapping spheres of power, it is useful to conceptualize the present era as a secular "neo-medieval world order." HELD ET AL., supra note 80 , at 85-86. As Bull analogizes the medieval era to the current global system, "In that system no ruler or state was sovereign in the sense of being supreme over a given segment of the Christian population; each had to share authority with vassals underneath, and with the Pope and (in Germany and Italy) the Holy Roman Emperor above." Id. 
stubbornly endured for over eight centuries in Andorra. Formed as a modus vivendi between the French Counts of Foix and the Bishop of Urgell, the condominium solution in Andorra continues to be a tangible testament to the viability of the condominium as a permanent solution. Although it is possible that the condominium solution in Andorra is sui generis due to Andorra arguably not being a condominium per se, a dearth of natural resources, isolation, or lack of cultural significance, the fact remains that Andorra remains an enduring power-sharing solution over a disputed territory between two authorities. More importantly, as the world enters into a post-Westphalian order and begins to place less importance on absolute sovereignty by joining international communities of pooled sovereignty, it may represent the potential for the condominium solution to once again be revived as a conceivable solution to disputed territories around the world. 
